\title{
Cell culture processes for monoclonal antibody production
}

\author{
Feng Li, ${ }^{1}$ Natarajan Vijayasankaran, ${ }^{2}$ Amy (Yijuan) Shen, ${ }^{3}$ Robert Kiss ${ }^{2}$ and Ashraf Amanullah ${ }^{1, *}$
}

'Oceanside Pharma Technical Development; Pharma Technical Development US Biologics; Genentech; Oceanside, CA USA; ${ }^{2}$ Late Stage Cell Culture; ${ }^{3}$ Early Stage Cell Culture; Pharma Technical Development US Biologics; Genentech; South San Francisco, CA USA

Key words: monoclonal antibody, expression systems, cell line engineering, cell culture process development, optimization scale-up and technology transfer, process advances

Animal cell culture technology has advanced significantly over the last few decades and is now generally considered a reliable, robust and relatively mature technology. A range of biotherapeutics are currently synthesized using cell culture methods in large scale manufacturing facilities that produce products for both commercial use and clinical studies. The robust implementation of this technology requires optimization of a number of variables, including (1) cell lines capable of synthesizing the required molecules at high productivities that ensure low operating cost; (2) culture media and bioreactor culture conditions that achieve both the requisite productivity and meet product quality specifications; (3) appropriate online and off-line sensors capable of providing information that enhances process control; and (4) good understanding of culture performance at different scales to ensure smooth scale-up. Successful implementation also requires appropriate strategies for process development, scale-up and process characterization and validation that enable robust operation and ensure compliance with current regulations. This review provides an overview of the state-of-the art technology in key aspects of cell culture, e.g., generation of highly productive cell lines and optimization of cell culture process conditions. We also summarize the current thinking on appropriate process development strategies and process advances that might affect process development.

\section{Introduction}

With the increasing number of protein therapeutic candidates, especially monoclonal antibodies (mAbs) entering various stages of development, biopharmaceutical companies are increasingly looking at innovative solutions to deliver this pipeline. For antibody manufacturing process development, maintaining desired quality attributes while reducing time to market, maintaining cost effectiveness, and providing manufacturing flexibility are key issues in today's competitive market, where several companies

*Correspondence to: Ashraf Amanullah; Email: Amanullah.ashraf@gene.com Submitted: 04/14/10; Accepted: 06/19/10

Previously published online:

www.landesbioscience.com/journals/mabs/article/12720

DOI: 10.4161/mabs.2.5.12720 are often working on therapies for similar targets and clinical indications. Since antibody therapies may require large doses over a long period of time, manufacturing capacity becomes an issue because the drug substance must be produced in large quantities with cost and time efficiency to meet clinical requirements and pave the way toward commercialization. In response to the strong demand, many companies have built large scale manufacturing plants containing multiple $10,000 \mathrm{~L}$ or larger cell culture bioreactors.

In terms of manufacturability and scalability, mammalian cells have historically been considered difficult to work with due to factors such as low yield, medium complexity, serum requirement, and shear sensitivity, although the latter has generally been incorrectly overemphasized. After two decades of intensive development work in cell line, media and bioreactor condition optimization, cell specific productivity of over $20 \mathrm{pg} /$ cell/day can be routinely achieved for production cell lines ${ }^{1}$ high titers up to $\sim 10$ $\mathrm{g} / \mathrm{L}$ and cell densities of over 20 million cells $/ \mathrm{mL}$ in fed-batch processes have been recently reported by a few companies at major conferences. The enhancement of specific productivity per cell is achieved not only by selection of highly productive clones, but also by optimization of medium composition and bioreactor operation conditions. Today, the combination of high titers and large capacity has gradually shifted the focus of cell culture process development from pursing even higher titers to controlling product quality and process consistency at all development stages and production scales. ${ }^{3}$

Cell culture process development starts with cell line generation and selection, followed by process and media optimization in small scale systems, including 96-well plates, shaker flasks, and bench-scale bioreactors, for high throughput screening purposes. Once conditions are defined, the process is often transferred to a pilot scale to test scalability and produce material for preclinical toxicology studies, and then larger scale manufacturing for production of clinical material under current good manufacturing practices (cGMP) regulations. Once development of a commercial cell culture process for production of a biological product is completed at the laboratory and pilot scales, the commercialization process begins with process characterization, scale-up, technology transfer, and validation of the manufacturing process. ${ }^{2}$

As cell culture technology is maturing, the biopharmaceutical industry has applied platform processes to satisfy material demand and quality requirements within a short period of time. 
Table 1. Selectable markers often used in mammalian expression vectors

\begin{tabular}{|cc|}
\hline Selectable marker & Selective reagent \\
\hline Metabolic selectable marker & $\begin{array}{c}\text { Methionine sulphoximine } \\
\text { (MSX) }\end{array}$ \\
\hline Dihydrofolate reductase (DHFR) & $\begin{array}{c}\text { Methotrexate (MTX) } \\
\text { Glutamine synthase (GS) }\end{array}$ \\
\hline Antibiotic selectable marker & Puromycin \\
\hline Puromycin acetyltransferase & Blastcidin \\
\hline Blasticidin deaminase & Histidinol \\
\hline Histidinol dehydrogenase & Hygromycin \\
\hline Hygromycin phosphotransferase & Zeocin \\
\hline Zeocin resistance gene & Bleomycin \\
Bleomycin resistance gene & Neomycin (G418) \\
\hline Aminoglycoside phosphotransferase & \\
\hline
\end{tabular}

The cell culture platform often consists of common host cell, expression vector, transfection and selection methods during cell line generation, and standard cell culture media, process control and scale up methodologies during process optimization. This approach not only enables fast process development, but also provides predictable performances in scale up, facility fit and downstream process integration.

\section{Mammalian Expression Systems}

Therapeutic antibodies are mainly produced in mammalian host cell lines including NS0 murine myeloma cells, PER.C6 ${ }^{\circledR}$ human cells, and Chinese hamster ovary $(\mathrm{CHO})$ cells. ${ }^{4-8}$ The selection of expression system is determined by its ability to deliver high productivity with acceptable product quality attributes and the preferences of individual companies, which is often influenced by their historical experiences.

Murine NS0 cells are non-immunoglobulin secreting myeloma cells that are cholesterol auxotrophs requiring the presence of cholesterol in culture medium for growth; ${ }^{9}$ however, cholesterolindependent NS0 cells also have been established. ${ }^{10-12}$ NSO cells lack endogenous glutamine synthetase (GS) enzyme activity making them suitable for use with GS as a selectable marker for recombinant antibody expression..$^{13}$ High antibody productivity has been reported from non-GS NS0 cell lines as well. ${ }^{14,15}$ Mousederived cell lines, including NSO, produce N-glycolylneuraminic acid (NGNA; a sialic acid that cannot be synthesized by humans) at appreciable levels. This sialic acid form was initially believed to present a potential immunogenicity concern in humans. It was later shown that $\mathrm{CHO}$ cells can express low levels of NGNA and that humans apparently incorporate NGNA into proteins from dietary sources, which tempered immunogenicity concerns. ${ }^{16-18}$ Murine cells, including NS0, do produce alpha-Gal-alpha $(1,3)$ Gal linkages, which humans have been shown to express antibodies against. Although NS0 cells have been used in industry to produce therapeutic antibodies, these potential immunogenicity aspects have likely limited use of these cells for therapeutic antibody production.
Compared to NS0 and $\mathrm{CHO}$ cells, PER.C6 ${ }^{\circledR}$ cells embody a relatively new technology. Cells are derived from human embryonic retina cells that have been immortalized by transfecting the E1 genes from adenovirus 5 DNA. ${ }^{19}$ Like NSO and $\mathrm{CHO}$ cells, PER.C6 ${ }^{\circledR}$ cells can proliferate indefinitely in suspension under serum-free conditions.

$\mathrm{CHO}$ cells are the predominant host used to produce therapeutic proteins. About $70 \%$ of all recombinant proteins ${ }^{20}$ produced today are made in $\mathrm{CHO}$ cells, including DUXB11, DG44 and CHOK1 lineages. DUXB11 and DG44 cells do not have dihydrofolate reductase (DHFR) activity, while CHOK1 cells have endogenous DHFR activity.

\section{Cell Line Development}

The process for development of a stable cell line starts with expression vector construction and transfection. After being transfected with plasmids bearing the antibody light and heavy chain genes, as well as selectable marker or markers, cells are screened for high productivity following growth recovery, serum-free suspension adaptation and amplification (if necessary) and clone selection. The screening and selection of a highly productive and stable clone from the transfectant population in a limited time frame is a major challenge.

Mammalian expression vectors typically contain one cassette for antibody genes and selectable marker gene(s) for expression in mammalian cells, and a second cassette for the genes enabling plasmid replication in bacteria. To achieve high levels of antibody expression, strong promoter/enhancers such as the cytomegalovirus (CMV) promoter ${ }^{21}$ and elongation factor alpha $(\mathrm{EF} 1 \alpha)$ promoter $^{22}$ are used to drive antibody heavy chain and light chain expression. Often an intron sequence in the $5^{\prime}$ untranslated region is included after the promoter/ enhancer to increase export of transcribed mRNA to the cytoplasm from the nucleus, and one or more 3 ' polyadenylation signal sequences are included to maximize mRNA levels. Commonly used polyadenylation signal sequences are the SV40 late or early polyadenylation signal sequences and the bovine growth hormone polyadenylation sequence. In addition to transcription, translation and secretion are also required for antibody production. Typically, a consensus Kozak sequence ${ }^{23}$ is created by placing GCC GCC $(\mathrm{A} / \mathrm{G}) \mathrm{CC}$ immediately in front of the first translation initiation codon to enhance translation initiation, while a signal peptide sequence is placed immediately in front of the mature antibody peptide to direct antibody protein secretion. ${ }^{13}$

A variety of transfection methods have been developed to stably introduce vector DNA into mammalian cells, including calcium phosphate, electroporation, cationic lipid-based lipofection, and polymer or dendrimer-based methods. ${ }^{24}$ All four methods have been used for stable transfection, but electroporation and lipofection are the most common choices. Transfected cells are then selected, relying on different selectable markers that can be categorized into two groups; metabolic selectable markers and antibiotic selectable markers. Some commonly used selectable markers are listed in Table 1. 
Table 2. Selected list of approved antibodies produced in $\mathrm{CHO}$ cells

\begin{tabular}{|c|c|c|c|}
\hline Product & Indication & Marketing company & First US approval \\
\hline Rituximab (Rituxan ${ }^{\mathrm{TM}}$ ) & Chronic lymphocytic leukemia & Genentech (Roche), Biogen Idec & 1997 \\
\hline Trastuzumab (Herceptin ${ }^{\mathrm{TM}}$ ) & Breast cancer & Genentech (Roche) & 1998 \\
\hline Alemtuzumab (Campath ${ }^{T M}$ ) & Chronic lymphocytic leukemia & Genzyme & 2001 \\
\hline Omalizumab (Xolair ${ }^{\top \mathrm{M}}$ ) & Allergic asthma & Genentech (Roche) & 2003 \\
\hline Bevacizumab (Avastin ${ }^{\top M}$ ) & Colorectal cancer & Genentech (Roche) & 2004 \\
\hline Panitumumab (Vectibix ${ }^{\top M}$ ) & Colorectal cancer & Amgen & 2006 \\
\hline Tocilizumab (Actemra ${ }^{\mathrm{TM}}$ ) & Rheumatoid arthritis & Chugai/Roche & 2010 \\
\hline
\end{tabular}

CHO stable cell lines have often been selected using metabolic selective markers including methotrexate (MTX) (dihydrofolate reductase gene mediated) and methionine sulphoximine (MSX) (glutamine synthetase gene mediated). ${ }^{13}$ Table 2 shows a selected list of approved antibody products produced in $\mathrm{CHO}$ cells. It has also been reported that an antibodyproducing cell line can be generated using two different selectable markers together. ${ }^{14}$ In cases where two selective markers have been used to select stable antibody-producing cell lines, the selective markers are located either in one expression construct also containing genes for heavy chain and light chain, or on two separate plasmids, each containing either the heavy or light chain gene.

We recently explored the "double selection" approach, which simultaneously transfects two

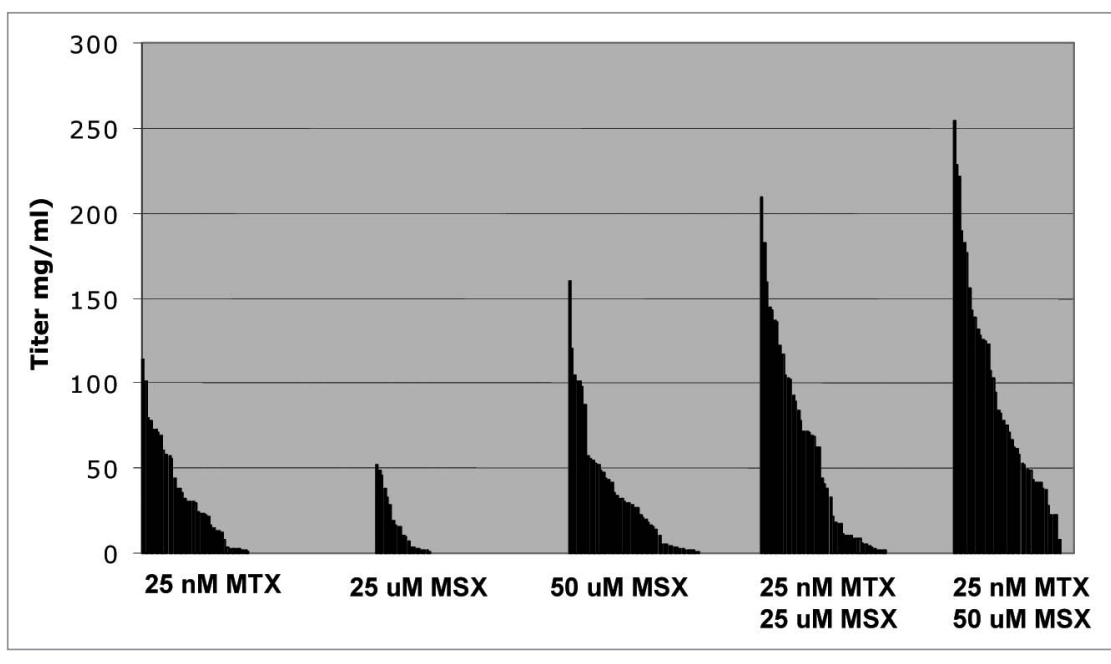

Figure 1. 96-well Elisa assay of clones from single and double selection. For each case, 72 clones were screened. [Notes: MTX, methotrexate; MSX, methionine sulphoximine]. plasmids into $\mathrm{CHO}$ cells for stable antibody

cell line generation. The unique feature of this approach is that each plasmid contains both the heavy chain and light chain genes, and one selective marker. Cells transfected with two plasmids are selected with two different selective reagents such as MTX and MSX. The productivity of clones generated using this approach was higher than that of clones transfected with either plasmid alone, as shown in our 96-well productivity assay (Fig. 1). To our knowledge, this is the first time that simultaneous transfection with two expression constructs and selection with two different selective markers has been successfully demonstrated as a means to generate highly productive stable $\mathrm{CHO}$ cell lines expressing antibody.

To generate stable cell lines with adequate productivity for clinical or commercial material production, hundreds to thousands of clones may be screened. The primary screen is usually an ELISA assay with or without cell number normalization, to eliminate non- or low producers. While high producers are scaled up, additional assays are performed to measure cell growth, cell specific productivity, and volumetric productivity (titer) in order to choose the top 12-24 clone candidates, which are typically further analyzed in a fed-batch cell culture scale-down models such as shake flasks or laboratory scale bioreactors. Product quality attributes such as glycosylation profile, charge variants, aggregate levels, protein sequence heterogeneity, as well as cell culture characteristics including growth, specific productivity, volumetric productivity, and clone stability, are assessed to enable selection of the top 4-6 clones for further evaluation in bioreactors, after which the final production clone and backup clone are chosen.

\section{Cell Line Engineering}

A significant amount of work has been done to genetically engineer production host cells to improve or modify the product quality or improve the host cell robustness. Glycosylation control has received a lot of attention because glycan structures on antibodies can have substantial effects on clearance rate and bioactivities. ${ }^{25}$ Antibodies produced in $\mathrm{CHO}$ cells typically have complex biatennary structures with very low or no bisecting-Nacetylglucosamine (bisecting GlcNAc) and high levels of core fucosylation. ${ }^{26}$ Overexpression of $\mathrm{N}$-acetylglucosaminyltransferase III has been used to increase the fraction of bisecting GlcNAc that resides on antibodies to improve antibody-dependent cellular cytotoxicity (ADCC). RNAi and gene deletion technologies have also been used to decrease or eliminate the fucose on antibodies to dramatically increase ADCC activity. ${ }^{27,28}$ In general, glycosylation is difficult to control precisely in mammalian cells as it is dependent on a variety of factors such as clonal variations, media, as well as culture conditions. 
Other areas of host cell engineering include approaches to decrease programmed cell death, reduce lactate accumulation, and manipulate cell growth. Overexpression of anti-apoptotic gene or genes and RNAi-technology mediated knock-down expression of apoptotic gene or genes have been used to extend the culture viability that leads to improved productivity. ${ }^{29}$ Since $\mathrm{CHO}$ cell and other continuously cultured cells have low efficiency in completely oxidizing glucose to $\mathrm{CO}_{2}$ and $\mathrm{H}_{2} \mathrm{O}$, one by-product of cell culture process is lactate accumulation, which can cause acidification of culture medium and lead to high osmolarity and low viability due to the alkali added to control the medium $\mathrm{pH}$. A significant amount of work ${ }^{30-32}$ has been performed to reduce lactate accumulation; however, the usefulness of this approach may be very clone dependent. ${ }^{31}$

Another area of research has focused on the use of inducible expression systems in mammalian cells. This strategy has the advantage of decoupling cell growth from product formation. Growth arrest in NS0 cultures via the inducible expression of p21 was reported to result in a significant increase in cell specific productivity. ${ }^{33}$ Current practice for the selection of high producing clones involves a time-consuming and laborious screening strategy due to the fact that the random integration of the transgene of interest gives rise to very different expression levels due to variation in the chromosomal surroundings or unpredictable cross-interactions of multiple gene copies. ${ }^{34}$ Several strategies have been proposed to overcome the positional dependency of random integration. One of the most promising methods is the use of homologous recombination systems for site-specific gene integration such as the Flp/FRT system from $S$. cerevisiae and the Cre-lox system from the bacteriophage P1 in eukaryotic cells. Coroadinha et al. ${ }^{35}$ used the Flp/FRT system to target gene insertion into a high expression chromosomal locus and succeeded in establishing a viral packaging 293 cell line for consistent hightiter virus production. Fukushige and Sauer ${ }^{36}$ demonstrated the use of a lox recombination vector to obtain stable transformants with predictable gene expression profiles. The positive selection vector system was designed to directly select Cre-mediated DNA integration at a lox target (using an inactive lox-neo fusion gene) previously placed into the genome of cultured cells. This technique ought to allow the rapid and efficient exchange of a single copy of the transgene of interest with no change in expression levels.

A pre-requisite to the application of this promising technology is the identification of integration sites that lead to high expression; however, it should be possible to investigate the position effects on gene expression using the site-specific DNA integration Flp/FRT and Cre-lox methods. For example, transfection of DHFR deficient $\mathrm{CHO}$ cells with a loxP-GFP fusion and DHFR genes and high-throughput screening via FACS was used to identify transcription active sites. ${ }^{37}$ Simultaneous transfection with two expression constructs and selection with two different selective markers as a means to generate highly productive stable $\mathrm{CHO}$ cell lines also appears promising. Overall, these methods should result in greater efficiencies in cell line screening for high producers and a further reduction in development timelines.
Several alternative expression systems such as Pichia pastoris and Escherichia coli have recently emerged as promising hosts for mAb secretion. ${ }^{38}$ Researchers at Glycofi (a subsidiary of Merck \& Co., Inc., NJ) have successfully demonstrated the feasibility of glyco-engineered $P$. pastoris cell lines to produce mAbs with highly specific glycoforms. ${ }^{39}$ Several different glycoforms of commercially available Rituximab (Rituxan; Genentech Inc., $\mathrm{CA}$ ) were generated, and binding to $\mathrm{F} c \gamma$ receptors and ADCC activity were measured. This study demonstrated a 10 -fold increase in binding affinity, as well as enhanced ADCC activity with the glycan-engineered proteins compared with Rituximab. Controlling the glycan composition and structure of IgGs thus appears to be a promising method for improving the efficacy of therapeutic mAbs that utilize ADCC for biological activity. Coupled with the use of well-established $P$. pastoris as a platform, processes that include high cell density cultures, scalability, costeffectiveness and existing large scale fermentation capacity can allow for high-fidelity production of human glycosylated therapeutic proteins.

E. coli has been most commonly used for production of antibody fragments such as Fabs that are utilized when Fc-mediated effector functions are not required or deleterious. ${ }^{39}$ Simmons et $a .^{40}$ demonstrated that efficient secretion of heavy and light chains in a favorable ratio resulted in the high-level expression and assembly of full-length IgGs in the E. coli periplasm. The technology described offers a rapid and potentially inexpensive method for the production of full-length aglycosylated therapeutic antibodies that do not have ADCC functionality. Mazor et al. ${ }^{41}$ also showed that it was possible to obtain full-length antibodies from combinatorial libraries expressed in E. coli. The full-length secreted heavy and light chains assembled into aglycosylated IgGs that were captured by an Fc-binding protein located on the inner membrane. Flow cytometry was used after permeabilization of the membrane and attachment of the antibody to a fluorescent antigen.

Aspergillus niger has also been used for the production of $\mathrm{mAbs}$ or antibody fragments; Ward et al. ${ }^{42}$ used $\mathrm{N}$-terminal fusion to glucoamylase for both heavy and light chains to express a full length IgG in this fungus. In addition, the use of cell-free protein synthesis for recombinant protein production is emerging as an important technology. Goerke and Swartz ${ }^{43}$ recently demonstrated the utility of the technology using $E$. coli cell extracts to produce a number of proteins, antibody fragments and vaccine fusion proteins, with correct folding and presence of disulfide bonds.

\section{Platform Process Development}

Due to the high degree of uncertainty associated with clinical studies, process development for biopharmaceuticals is often divided into an early and late stage, with each having different emphasis (Fig. 2). The goal of early stage development is to rapidly develop bioprocesses to produce materials for Phase 1 or 2 clinical trials and animal toxicology studies. In order to accelerate filing of an investigational new drug (IND) application 


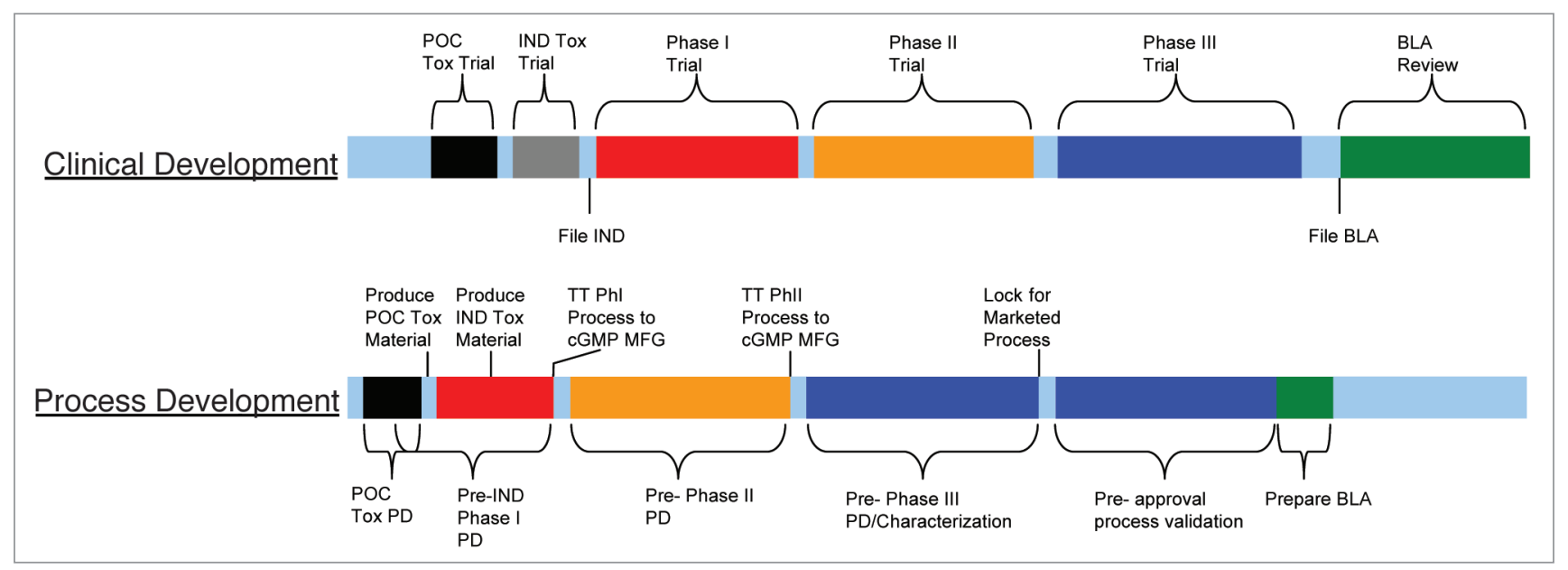

Figure 2. Clinical and process development flowchart. [Notes: POC, proof of concept; IND, investigational new drug application; Tox, Toxicology; BLA, biologics license application; TT, technology transfer; cGMP MFG, current good manufacturing practices compliant manufacturing; PD, process development].

for proof-of-concept clinical studies, it is becoming increasingly necessary for companies to deliver their pipelines efficiently by utilizing streamlined cell culture platform processes that include standardized process conditions and procedures. Use of a platform process allows acceleration of early stage cell culture process development activities, e.g., clone selection, process lock and technology transfer to clinical manufacturing. The similarity of molecular characteristics and properties among different mAbs makes the platform approach feasible, although the processes may not be fully optimized for every molecule.

As the product moves into late stage development, i.e., for Phase 3 and commercial production, the processes can be further optimized. Late stage process development is focused on improvements of process yield, robustness, scalability and regulatory compliance. Optimization of the process is an integrated activity involving clone selection, medium development, and bioreactor condition optimization, which is followed by scaleup to an appropriate manufacturing facility. Product quality and comparability needs to be closely monitored when process changes occur during both early and late stage development to ensure patient safety. To gain regulatory approval for commercialization, processes also need to be characterized to evaluate the effects of process parameters on process performance and product quality; the process should also be validated to demonstrate process consistency before commercial cGMP production.

\section{Clone Selection}

Selection of the final production clone is generally considered to be one of the most critical decisions in both early and late stage cell culture process development. Since changes in production cell lines during clinical development are considered major process changes, product comparability must be demonstrated if the cell line is changed during late stage development. Changing the cell line after Phase 3 clinical study typically requires additional human clinical studies. It is thus important to select the right clone prior to Phase 3 production of drug substance, and preferably at the Phase 1 stage.

After being transfected, cells are diluted and cultivated in 96-well plates with a basal growth medium and screened for robust cell growth and high productivity. At this stage, in order to predict clone performance in large-scale production bioreactors, an enriched medium that is similar to the final production medium formulation and a similar feeding regime can be tested in shake flasks or in small-scale bioreactors. Several clone attributes should be considered and evaluated for features such as product quality, manufacturability, and volumetric productivity.

Maintaining consistent and comparable product quality is a challenge if changes to cell line, media or other process changes are made as product candidates move forward from small-scale development lab to pilot plant scale, and eventually to commercial scale cGMP manufacturing. ${ }^{44-46}$ Among these variables, the cell line has the most significant impact on many quality attributes because these attributes are clone dependent. Some common analytical assays and quality assessment criteria employed during clone selection to test $\mathrm{mAb}$ molecular properties are summarized in Table 3.

Process yield is another critical criterion used to select the production clone. Since antibody expression rate in mammalian cells is usually non-growth associated, the final titer is equal to specific productivity Qp multiplied by the integral of viable cell density over culture duration, i.e., Titer $=\mathrm{Qp} \bullet \int \mathrm{X} d \mathrm{~d}$. To date, typical production cell line specific productivities range from $20 \mathrm{pg} /$ cell/day to $70 \mathrm{pg} / \mathrm{cell} /$ day and peak viability cell densities from $5-30 \times 10^{6}$ cells $/ \mathrm{mL}$ in a $10-14$ day fed-batch process.

Cell line stability is another factor that should be considered since volumetric and specific productivity decline as cell age increases for some cell lines. Such unstable clones are not suitable for large-scale production since cell age increases with scale as the cell culture process is scaled up through serial culture passages of the seed train and inoculum train. In addition to cell line stability, growth and metabolite characteristics that can affect process 
Table 3. Product quality assessment during clone selection

$\begin{array}{ccc}\text { Quality attribute } & \text { Analytical assay } & \text { Quality assessment criteria } \\ \text { Molecule integrity } & \text { cDNA sequence, Peptide mapping, CE-SDS or SDS-PAGE } & \text { Avoid amino acid sequence mutation or truncated antibodies } \\ \text { Aggregation } & \text { Size Exclusion Chromatography (SEC) } & \text { Avoid high level of aggregation, which could be immunogenic. } \\ \text { Glycosylation } & \text { HPLC or CE based glycan assay } & \text { Avoid high levels of unusually glycosylation forms } \\ \text { Charge heterogeneity } & \text { IEF or iCIEF, lon Exchange Chromatography HPLC } & \text { Avoid usually high levels of acidic or basic variant, or extra } \\ \text { acidic or basic peaks }\end{array}$

$\mathrm{CE}$, capillary electrophoresis; IEF, Isoelectric focusing; iCIEF, Imaged capillary isoelectric focusing.

robustness and scalability also need to be assessed. Robust cell growth with high viability and low lactate synthesis is usually desirable. High lactate producing clones are not preferred in order to avoid the dramatic osmolality increase that accompanies the addition of base needed to maintain $\mathrm{pH}$.

Screening and selection of highly productive and scalable clones among the transfectant population in a limited time frame is still a major challenge because the product quality, productivity and even cell metabolic profiles are often dependent on cell culture conditions. Using miniaturized high throughput bioreactors with full process parameter controllability to mimic the large-scale bioreactor environment could help to identify the best production clone at a very early stage.

\section{Medium and Feeding Strategy Development}

In general, medium development for a fed-batch process involves batch medium and feed concentrate development, as well as feeding strategy optimization. Several approaches can be used systematically, such as single-component titration, spent medium analysis, and medium blending. 47,48 Due to safety concerns related to transmissible spongiform encephalopathy (TSE) and other contaminants, bovine serum and animal-derived raw materials should be avoided if possible. After two decades of media development and host cell adaptation, fully chemically defined media consisting of amino acids, vitamins, trace elements, inorganic salts, lipids and insulin or insulin-like growth factors, have been developed and implemented in large-scale mAb production, but not all antibody production cell lines can achieve high yield in chemically defined media. Addition of animal-component-free hydrolysates to chemically defined media is a common approach to increase cell density, culture viability and productivity in a timely manner. Hydrolysates are protein digests composed of amino acids, small peptides, carbohydrates, vitamins and minerals that provide nutrient supplements to the media. ${ }^{49,50}$ Nonanimal derived hydrolysates from soy, wheat and yeast are used commonly in cell culture media and feeds; however, because of its composition complexity and lot-to-lot variations, hydrolysates can be a significant source of medium variability.

While the most common approach to develop a feed medium is to concentrate the basal medium, sophisticated optimization of feed composition and feeding strategy requires consideration of nutrient consumption, by-product accumulation and the balance between promoting growth versus volumetric productivity. ${ }^{51,52}$ Previous studies indicated that by-products such as lactate and ammonia could be minimized by maintaining low glucose and glutamine concentrations through frequent or continuous feeding $;{ }^{53}$ however, the operational complexity and cost of validating continuous feeding strategies have generally made them less desirable for large-scale manufacturing. Step-wise bolus addition of the feed solution to the production bioreactor is most widely used in industry due to its simplicity and scalability. In general, medium development is labor-intensive and time-consuming. A combination of high-throughput cell culture scale-down systems with statistical design of experiment (DOE) approaches is commonly applied to shorten development time. ${ }^{54,55}$

While optimization of cell culture media is often considered to be cell line dependent and best accomplished if based on the metabolism and nutrient consumption of specific cell lines, the aggressive timelines under which cell culture processes are developed requires development of a "platform" approach for optimization of cell culture processes. While the platform process might not provide the greatest volumetric productivity that could be achieved with specific cell lines, it will have wide applicability across multiple cell lines such that it can be implemented with minimal modifications for cell lines derived within the company. Hence, development of the platform process is accomplished with multiple cell lines that are representative of the various growth, productivity and metabolic phenotypes commonly observed. If business need dictates that processes for specific cell lines be optimized further, the platform process could be used as a starting point to enhance the cell culture process to achieve specific process goals such as higher volumetric productivities. Titers as high as $8 \mathrm{~g} / \mathrm{L}$ have been achieved with such process enhancements; Figure 3 illustrates antibody concentration profiles for the same cell line when operated under the platform media or enhanced media.

\section{Bioreactor Optimization and Scale Up}

Culture operating parameter optimization is required to achieve high expression of product with acceptable product quality profiles. These parameters are physical, chemical and biological in nature. Physical parameters include temperature, gas flow rate and agitation speed, while chemical parameters include dissolved oxygen and carbon dioxide, $\mathrm{pH}$, osmolality, redox potential and metabolite levels, including substrate, amino acid and waste byproducts. Biological parameters are used for determining the physiological state of the culture and include viable cell concentration, viability and a variety of intracellular and extra-cellular measurements such as NADH, LDH levels, mitochondrial activity and cell cycle analysis. Variations in the micro-environment 
parameters from optimal levels can have a dramatic impact on culture performance, productivity and product quality. A typical stirred tank bioreactor is equipped with temperature, pressure, agitation, $\mathrm{pH}$ and dissolved oxygen controls. Figure 4 illustrates the affects of cell culture operating strategies and parameters on culture environmental conditions such as dissolved oxygen (DO), pH, osmolality, dissolved $\mathrm{CO}_{2}$, mixing, hydrodynamic shear and how the environment consequently influences measures of process performances such as cell growth, metabolite concentrations, product titer and product quality.

Due to the complexity of protein products that include isoforms and microheterogeneities, the performance of the cell culture process can have significant effects on product quality and potency, especially with respect to glycosylation, post-transcriptional modifications and impurity profiles. ${ }^{44-46,56}$ Therefore, the bioreactor operating parameters have to be optimized and characterized thoroughly to improve process performance and understanding of how the process affects product quality. Significant progress has been made in the last two decades in understanding the impact of the cellular environment on culture physiology and its subsequent impact on productivity, product quality and downstream processes.

Another reason for the resurgence of research activity and innovation in this area can be attributed to the United States Food and Drug Administration's (FDA) process analytical technology (PAT) initiative..$^{57}$ The PAT directive is a "system for designing, analyzing, and controlling manufacturing through timely measurements (i.e., during processing) of critical quality and performance attributes of raw and in-process materials and processes, with the goal of ensuring final product quality". It also encourages a better understanding of the manufacturing process by identifying relationships between process parameters and reproducibility, culture performance and product quality attributes. Although originally conceptualized for small molecule manufacturing processes, it is increasingly being extended to biological processes, which are inherently more complex. ${ }^{58}$

Process parameters can be measured either on-line (or atline by direct connection to calibrated analyzers) or off-line via operator intervention. Typical examples of off-line measurements include $\mathrm{pH}$ (usually for verification of on-line $\mathrm{pH}$ readings), cell counting and viability measurements using a hemocytometer or automated cell counters, packed cell volume, osmolality and certain metabolite concentrations. Accurate gas and liquid flow measurements are typically conducted using mass flow meters and magnetic meters. Temperature can be measured accurately using commercially available resistance temperature devices
(RTD), although thermocouples can also be used; this parameter is usually shifted during the course of the fed-batch culture to extend culture longevity, potentially by manipulating the cell cycle. The temperature shift of the culture is often from $37^{\circ} \mathrm{C}$ to $30-35^{\circ} \mathrm{C}$ at 48 hours post inoculation, which can retain cells in $\mathrm{G}_{1}$ phase longer, and therefore delay the onset of apoptosis. ${ }^{59-61}$

Dissolved oxygen is typically controlled at a specific set point, usually between $20-50 \%$ of air saturation in order to prevent dissolved oxygen limitation, which might lead to excessive lactate synthesis, and excessively high dissolved oxygen concentrations that could lead to cytotoxicity. ${ }^{62}$ The Clark type electrode is still the most commonly used for measurement of dissolved oxygen. In this type of electrode, oxygen diffuses through a permeable membrane and is reduced at a negatively polarized cathode (platinum) with respect to a reference anode. The cathode and anode are separated by an electrolyte solution and the reduction of oxygen generates a voltage dependent current that is directly proportional to the dissolved oxygen concentration. Although cell growth is relatively insensitive to dissolved oxygen in the range $20-100 \%$ air saturation, ${ }^{63,64}$ the dissolved oxygen level can significant affect product quality. Kunkel et al. reported that reduction in dissolved oxygen caused decreased glycosylation of antibody N-glycan chains. ${ }^{65}$

Dissolved $\mathrm{CO}_{2}$ is also an important process variable because it can accumulate to inhibitory levels at values greater than 120-150 $\mathrm{mm} \mathrm{Hg}^{66-68}$ and affects product quality. Even though dissolved $\mathrm{CO}_{2}$ sensors are commercially available, e.g., from YSI Inc., (Yellow Springs, OH) or Metler Toledo (Columbus, OH), dissolved $\mathrm{CO}_{2}$ is still measured using off-line blood gas analyzers such as those from Nova Biomedical (Waltham, MA). The use 


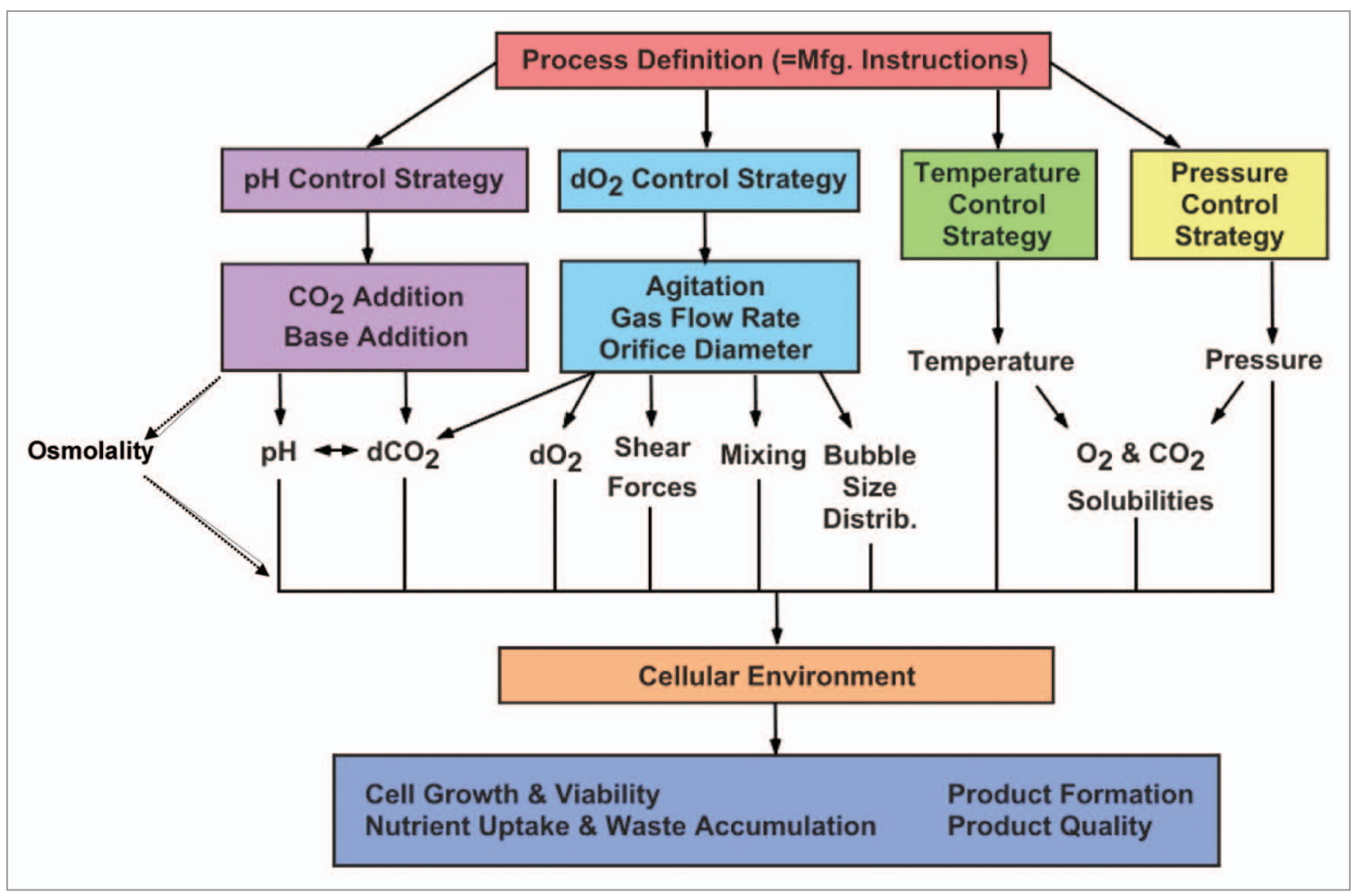

Figure 4. Cell culture process operating parameters affect process performance and product quality.

of in-situ sensors is not required because it is generally possible to match $\mathrm{CO}_{2}$ profiles at different scales by the correct choice of bioreactor sparger design, agitation speed and gas sparge rates. Measurement of oxygen uptake and $\mathrm{CO}_{2}$ production rates can also be achieved using on-line mass spectrometry. Unlike microbial fermentations, this type of analysis is rarely conducted due to the cost of such instrumentation and the lack of sensitivity of measurements at the very low rates of metabolism commonly observed in animal cells.

Since even a small deviation of 0.1 units from the optimal $\mathrm{pH}$ value can significantly impact culture growth and metabolism, in particular glucose consumption and lactate production, $\mathrm{pH}$ is an important variable to measure and control. ${ }^{69,70}$ Cell culture media usually contains sodium bicarbonate as buffering agent, and $\mathrm{pH}$ is usually tightly controlled with a combination of $\mathrm{CO}_{2}$ sparging to reduce $\mathrm{pH}$ and base addition to increase it. High $\mathrm{pH}(\geq 7.0)$ is usually preferred for initial cell growth phase, which is usually accompanied by lactate accumulation. When lactate accumulation exceeds the buffering capacity of the culture medium, $\mathrm{pH}$ drifts downward, which could trigger base addition leading to increased osmolality of the culture medium. This could be risky in cell lines that synthesize excessive amounts of lactate since high $\mathrm{pH}$, high lactate and high osmolality cascade often causes delayed cell growth and accelerated cell death. When cell growth has ceased, lactate is either produced at a much lower rate or consumed. The concomitant upward drift in $\mathrm{pH}$ is counteracted by $\mathrm{CO}_{2}$ sparging. Thus, the $\mathrm{pH}$ set-point and control strategy, e.g., dead band, are intimately linked to dissolved $\mathrm{CO}_{2}$ levels, base consumption for $\mathrm{pH}$ control and therefore, osmolality.
While a pH control strategy characterized by a wide dead band around the set-point that would allow the culture $\mathrm{pH}$ to drift without triggering the addition of base or $\mathrm{CO}_{2}$, could be a viable alternative to control either the osmolality or dissolved $\mathrm{CO}_{2}$, it is generally not preferred due to potential variability in $\mathrm{pH}$ profiles that could be observed in different scales. Thus, balancing the impact of $\mathrm{pH}$ on cell growth, lactate synthesis, osmolality and dissolved $\mathrm{CO}_{2}$ profiles needs to be a key consideration during process optimization. These considerations make the accurate measurement of $\mathrm{pH}$ even more imperative. $\mathrm{pH}$ probes typically consist of a $0.2-0.5 \mathrm{~mm}$ glass membrane fabricated from silicate groups containing sodium that form a hydrated gel layer on the membrane when placed in liquid. $\mathrm{An} \mathrm{Ag} / \mathrm{AgCl}_{2}$ electrode in $\mathrm{KCl}$ electrolyte saturated with $\mathrm{AgCl}_{2}$ is used to measure the change in potential of the outer surface of the membrane caused by changes in the medium $\mathrm{pH}$. Use of $\mathrm{pH}$ probes for extended culture duration could lead to drift and reduced sensitivity, and hence on-line measurements are verified with periodic off-line measurements.

Most cell culture media are designed to have an osmolality in the range $270-330 \mathrm{mOsm} / \mathrm{kg}$. Culture osmolality is routinely measured using freezing-point depression osmometry. Various commercial systems are available, although the analyzers from Advanced Instruments (Norwood, MA) are the most commonly employed in cell culture and are capable of measuring osmolality in the range of $0-1,500 \mathrm{mOsm} / \mathrm{kg}$ of water. The impact of osmolality is cell line specific; deZengotita et al. reported growth inhibition with increasing osmolality and effects on cell specific productivity. ${ }^{71}$ These deleterious effects could be exacerbated when combined with high dissolved $\mathrm{CO}_{2}$ levels that could occur 


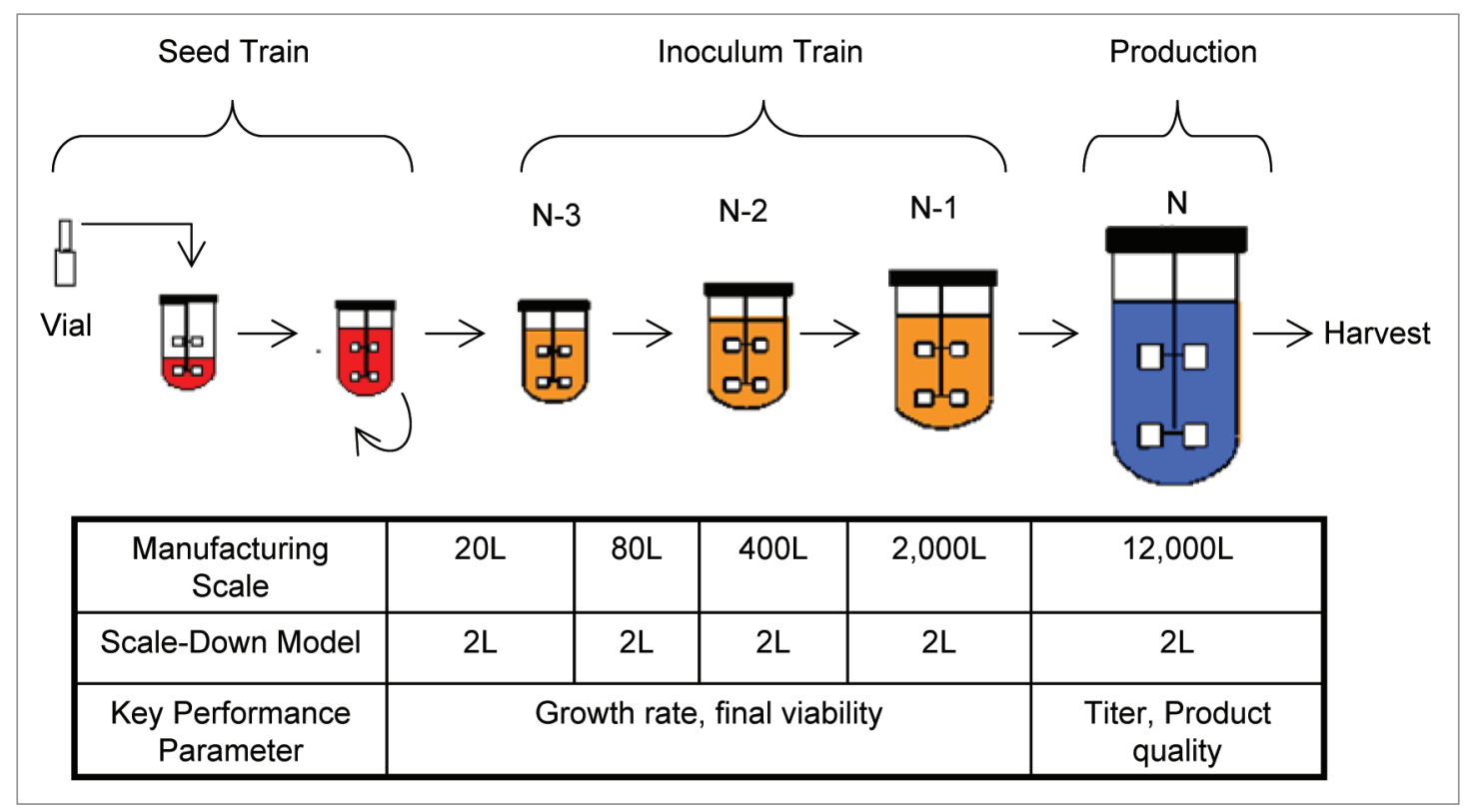

Figure 5. A large-scale cell culture process steps and their key process performance parameters.

in high cell density cultures, ${ }^{72}$ and hence it is vital to ensure during process development that the osmolality profile is acceptably low, especially towards the latter stages of the cell culture process. There are also examples, however, where a high culture osmolality has been used to leverage an increase in specific productivity balanced with a reduction in cell growth to yield an increased volumetric productivity compared to lower osmolality. ${ }^{73,74}$

Cell culture metabolites such as glucose, lactate, glutamine and glutamate are commonly measured off-line using enzymatic biosensors specific to the measured analyte. These measurements are important not only for maintaining substrate levels above critical levels via feeding strategies, but also in developing processes with reduced by-product formation. Commercially available instruments include the YSI 2700 from YSI Inc., (Yellow Springs, $\mathrm{OH}$ ) or Nova Bioprofile 400 from Nova Biomedical (Waltham, MA). These analyzers employ biosensors where the reaction of a substrate with the enzyme produces a product that can be readily measured. For example, glucose can be detected using glucose oxidase in the presence of excess oxygen to produce gluconic acid and hydrogen peroxide. A second reaction between fluorescein and the $\mathrm{H}_{2} \mathrm{O}_{2}$ produced from the first reaction produces a fluorescent signal that correlates directly to the glucose concentration. In addition to the quantification of metabolites, the Nova Bioprofile 400 can also measure $\mathrm{pH}$, dissolved gases $\left(\mathrm{O}_{2}\right.$ and $\left.\mathrm{CO}_{2}\right), \mathrm{NH}_{4}{ }^{+}(0.20-25.00 \mathrm{mM}), \mathrm{Na}^{+}(40.0-220.0 \mathrm{mM})$, $\mathrm{K}^{+}(1.00-25.0 \mathrm{mM})$ and $\mathrm{Ca}^{++}(0.10-10.0 \mathrm{mM})$. It is important to point out that accurate measurements with these systems require proper maintenance and calibration procedures.

Cell concentration and viability measurements are critical in developing cell culture processes and are used for determining culture physiology in response to operating conditions and calculation of growth rates, specific consumption/production rates of metabolites and cell specific productivity. The most common method for measuring cell concentration and viability is via Trypan Blue exclusion microscopy. This method depends upon the ability of cells with intact membranes, i.e., live cells, to exclude Trypan Blue; those that stain blue are classified as dead cells. A number of automated analyzers that exploit this method and are coupled to image analysis are commercially available (Cedex, Innovatis, Bielefeld, Germany and Vi-Cell, Beckman Coulter, Fullerton, CA). These analyzers also allow the determination of cell size. In many cell culture processes, the mean cell size can change by as much as $50 \%$ (or over a 3 -fold change cell volume).$^{75}$ In these cases, it is insufficient to measure viable or total cell concentration. Instead, packed cell volume (or viable packed cell volume) is determined using centrifugation based methods; this is more likely to provide an accurate representation of the cell mass since it avoids instrument associated variability, which is especially useful during technology transfer between different sites.

The Trypan Blue exclusion method does not allow measurements other than live or dead. Multi-parameter flow cytometry using fluorescent dyes such as propidium iodide and annexin V or caspase 5 can be used to quantify live/dead cells and apoptotic cell populations. This is now possible in cell culture laboratory settings using relatively simple 96-well plate based systems and specifically designed measurement kits for such analyses, as well as a multitude of other cell based assays (Guava Technologies, Hayward, CA). Measurements of cell metabolic activity can be quantified by on-line oxygen uptake rate measurements or offline cell mitochondrial activity using FACS.

After development, process performances achieved on small scales should be maintained during scale up. A typical largescale cell culture process consists of a number of unit operations, including seed train, inoculum train, and production run (Fig. 5). Each step has its key process performance indicators such as cell growth, viability and titer, along with appropriate product quality attributes. The success of process scale up is usually 
measured by these key process indicators and product quality attributes that meet pre-defined criteria.

Mammalian cells are generally considered difficult to scale up due to their sensitivity to physico-chemical conditions. Scale up of high cell density process to large-scale bioreactors by providing sufficient oxygen supply and $\mathrm{CO}_{2}$ removal can be challenging in some cases, and requires proper selection of large-scale bioreactor operating parameters. ${ }^{76}$ Bioreactor operating parameters can be categorized into volume-dependent parameters, e.g., working volume, feed volume, agitation, aeration and volume-independent parameters, e.g., $\mathrm{pH}$, dissolved oxygen, temperature. A general strategy for scale-up is to proportionally scale up the volume-dependent parameters while maintaining the volumeindependent parameters at the same set points used in the smallscale process, although some volume-dependent parameters are difficult to scale up/down linearly due to differences in bioreactor geometry, liquid surface to volume ratio, gassing regime and control capability, i.e., non-linear effects apply.

During bioreactor operating condition scale up, agitation and aeration are two important conditions to be scaled up properly to achieve comparable process performance across different scales. Agitation is adjusted to provide sufficient mixing and oxygen mass transfer and is generally scaled using equal specific energy dissipation rate, whereas aeration is modulated for appropriate supply of oxygen and removal of excess $\mathrm{CO}_{2} \cdot \mathrm{CO}_{2}$ removal could depend on a number of factors, including concentration of bicarbonate, aeration and agitation rates, bubble size and the type and positioning of the impeller. ${ }^{67,72,76}$ In small scale bioreactors, the operable ranges of operating parameters are typically wide because mixing is generally not a problem even at relatively low agitation speeds and dissolved $\mathrm{CO}_{2}$ removal is efficient due to large surface to volume ratio. In large-scale bioreactors, these parameters need to be selected carefully as agitation-related shear forces, e.g., impeller tip speed and aeration related $\mathrm{CO}_{2}$ accumulation may increase with scale.

Beside large-scale bioreactor operational challenges, other common pitfalls of cell culture process scale up include lot-tolot variations of raw material, consistency of media preparation, media hold stability, and cell line stability during the long duration of the manufacturing process. These issues can often be identified using scale-down models. A qualified cell culture scale-down model that is able to reproduce large scale process performance at small scale provides crucial information needed to assess and resolve any unexpected performance problem of the large-scale system. ${ }^{2}$ Beyond manufacturing support, the scale-down model can also be used for process characterization and validation experiments to study acceptable ranges of process operating parameters and determine the critical operating parameters.

\section{Process Characterization and Validation}

The FDA defines process validation as "establishing documented evidence that a specific process will consistently produce a product meeting its predetermined specifications and quality attributes". ${ }^{77,78}$ This regulatory requirement reflects the recognition that the product quality can be substantially affected by the manufacturing process. To meet this requirement, the process needs to be fully characterized and validated to understand the impact of process inputs (operating parameters) on process outputs (performance indicators and quality attributes). Product quality specifications are established and approved as part of the biologic license application (BLA).

Since the effect of process parameters on key performance indicators and quality attributes may vary for different cell culture steps, each operation may need to be characterized and validated separately. Process characterization and validation usually occurs after the completion of Phase 3 process development, when the manufacturing process is locked and no further significant changes are expected. Although much process characterization and validation work can be performed using qualified scale-down models, full-scale process validation is required to demonstrate consistent process performance and product quality when controlling critical process parameters within pre-defined acceptable ranges at commercial scale. For validation purposes, three and five consecutive full-scale runs are normally required for BLA approval in the US and EU, respectively.

The objectives of process characterization include identification of critical operational parameters and key performance indicators, establishment of acceptable ranges for operational parameters, and demonstration of process robustness. ${ }^{2,79,80}$ Technical information from the characterization studies has also become a regulatory expectation in recent years as a prerequisite for manufacturing process validation, as well as for long-term commercial manufacturing support. ${ }^{77,78}$ Since performing a characterization study at the manufacturing scale is not practically feasible due to the cost of operation and limited availability of large-scale bioreactors, scale-down models that represent the performance of manufacturing scale process are usually employed.

It is also important to use qualified analytical methods and raw materials throughout the characterization studies for consistency and accuracy. Cell culture process characterization requires support from the purification and analytical groups to test process impact and monitor product quality. Some cell culture materials from characterization studies can be used as feed stream for downstream process characterization, especially for robustness studies, e.g., linkage between upstream and downstream unit operation performance.

\section{Process Technology Transfer and cGMP Manufacturing}

Once a scalable process is locked at laboratory and pilot scales, it needs to be transferred to a manufacturing facility for cGMP production of clinical or commercial product. The purpose of technology transfer is to transfer all of the necessary process information, documentation, equipment, materials, and tools in order to implement the manufacturing process at a specific facility and obtain regulatory approval. The technology transfer typically requires collaborations among different groups including Process Development, Manufacturing, and Quality. ${ }^{81}$ The activities required to successfully transfer a cell culture process 
can be organized into several stages, including process/facility gap analysis, process/facility, equipment modification and qualification, engineering runs at full scale if needed, cGMP commissioning, and cGMP production.

Before a new process is introduced into an existing facility, a "gap analysis" should be conducted to identify limitations and potential risks to fit the manufacturing process into the facility. The facility and equipment modifications and qualification activities should be completed prior to full-scale production runs. Moreover, as the product moves from early stage (Phase 1 or 2 clinical studies) to late stage (Phase 3 through commercialization) production at different scale facilities, the process may need to be modified to reflect scale and facility changes. In this case, modifications should be minimized as much as possible and any changes made to the process need to be qualified to ensure product quality comparability before and after such change.

In general, regulatory authorities do not require that the pre- and post-change product are identical, but rather that their physicochemical properties and biological activity are highly comparable, and these changes have no impact upon the safety or efficacy of the product. ${ }^{78,82}$ Non-GMP engineering runs are typically conducted to test process performance at full scale to ensure process and product quality consistency. Prior to the initiation of the cGMP production, cGMP commissioning should also be completed to ensure that the facility, raw material, documentation, personnel training, quality control and production systems are ready.

\section{Process Advances}

While cell culture technology is today considered well-established and reliable, new technologies are being explored to make the processes even more robust, and to reduce the cost of operation. These technologies involve the development of highthroughput cell culture systems, new on-line process monitoring and control systems and the use of disposable technologies. To deliver a robust and productive process while maintaining aggressive timelines to introduce the molecular candidate in to the clinic, increasing throughput of development experimentation has become progressively more important to rapidly screen and optimize process parameters. ${ }^{83,84}$

Small scale systems such as shake flasks and spinner flasks have been used to screen large number of clones and experimental conditions, but these models are less desirable for bioprocess optimization due to the laborious nature of shake flask experimentation and the inability to monitor or control environmental parameters or conduct fed-batch cultivations on a routine basis. Several scale-down systems with different levels of sophistication have been proposed to overcome these limitations. One such system currently in use, called "TubeSpin", is based on $50 \mathrm{~mL}$ centrifugation tubes that have been configured as suspension cell culture vessels. They are especially useful for large screening experiments that do not require the measurement and control of $\mathrm{pH}$ and dissolved oxygen. ${ }^{85}$

A number of new microbioreactor systems that enable more sophisticated control of culture conditions, at sub-milliliters to tens of milliliters of working volumes, are also being evaluated $^{86-88}$ for robustness, reliability and scalability. It is conceivable that one or more of these systems could be used more widely for automated screening of a large number of culture conditions.

Monitoring of cell cultures through use of robust and accurate in situ sensors or at-line instruments coupled to automated sampling systems to measure relevant parameters could enhance the development and optimization of cell culture processes. The BioProfile ${ }^{\circledR}$ FLEX is an example of an integrated analyzer that combines the functionality of many commonly utilized instruments for $\mathrm{pH}$, dissolved gases, metabolites, cell counting, and osmolality into a single unit. The BioProfile ${ }^{\circledR}$ FLEX has been evaluated with fed-batch cultures using multiple cell lines and the measurements were found, in general, to be equivalent to the results using the aforementioned instruments. ${ }^{89}$ This advance is especially beneficial when combined with on-line automated sampling systems, and has the potential to reduce resources for conducting small-scale development experiments.

On-line optical cell density probes, based on light backscatter have been used successfully to monitor cell cultures..$^{90}$ Such measurements are generally linear with cell concentration only at high viabilities, and deviate significantly from linearity with decreasing culture viability, which commonly occur in the latter stages of fed-batch cultures. To overcome such limitations, dielectric permittivity and electrical impedance spectroscopy can be used to monitor viable cell volume. ${ }^{91}$ Spectroscopy, particularly using near or mid-infrared is an attractive alternative for the measurement of cell culture components, including substrates, waste products, amino acids, cell concentration and viability. Several studies have been published demonstrating the usefulness of this technique for monitoring cell culture media components. ${ }^{92-95}$

Non-invasive fluorescence sensor technologies have been used for on-line monitoring of cell culture parameters such as optical density, $\mathrm{pH}$ and dissolved oxygen for high-throughput applications. ${ }^{96}$ Due to limitations associated with each of these technologies, they are in various stages of evaluation and implementation. Nevertheless, it is to be noted that they have the potential to improve process knowledge, and thereby aid in the implementation of PAT.

Stainless steel tanks have traditionally been used at laboratory and pilot scales for process development and production of research grade, toxicology and Phase 1 clinical materials. Stainless steel tanks also dominate large-scale manufacture $(>1,000$ $25,000 \mathrm{~L}$ ) of biotherapeutics; however, the use of fixed plant equipment is costly, requiring long lead times for installation of the tanks and supporting infrastructure and qualification. There is also a high burden from validation efforts related to sterility and cleaning, as well as maintenance.

To overcome some of these challenges, several single use bioreactors (SUB) are being currently evaluated.9798 Companies marketing these systems include GE Healthcare, Sartorius, HyClone, Hynetics, ATMI, Xcellerex, Applikon and CELLution. Disposable technologies offer significant advantages over traditional fixed plant equipment, particularly at pilot scales of operation. They can be introduced rapidly into laboratory and manufacturing facilities since installation, qualification and 
personnel training requirements are minimal. They are provided clean and pre-sterilized and offer increased reliability. In addition, they can increase plant capacity and flexibility by reducing turnaround time, especially in the event of contaminations, decreasing set-up time, and demanding a smaller footprint due to significantly reduced piping, valve and instrumentation requirements. Implementing design changes is also more rapid with disposables, allowing for continuous improvement and integration of new technologies such as on-line monitoring systems. Overall, these advantages lead to significantly lower capital costs and lower resource requirements, which are key considerations for both large and small companies alike.

\section{Future Perspectives}

The past two decades have seen significant advances in cell culture technology that have increased the expression of recombinant proteins from $100 \mathrm{mg} / \mathrm{L}$ to several g/L. Furthermore, this technology is today considered robust and reliable for the synthesis of
mAbs both for commercial use and conducting clinical studies. These advances have resulted from intensive research in cell line engineering, media development, feeding strategies, cell metabolism, better process understanding and their impact on product quality and scale-up. It is expected that better understanding of cell biology fueled by advances in genomics, proteomics and metabolomics, including the application of gene expression analysis using $\mathrm{CHO}$ chips and genomic scale models, ${ }^{99,100}$ combined with further improvements in media, high throughput technologies, online monitoring and automation, will allow researchers to broaden the experimental design space, as well as lower the cost of process development.

\section{Acknowledgements}

The authors are grateful for the valuable contributions and technical discussions by Domingos Ng, Darren Brown, Cary Opel, Aaron Chen, Gayle Derfus, Daniel Abramzon, Terrence Allotta, Terry Hudson, Brad Snedecor, David Chang, John Joly and Dana Andersen.

\section{References}

1. Wurm FM. Production of recombinant protein therapeutics in cultivated mammalian cells. Nat Biotechnol 2004; 22:1393-8.

2. Li F, Hashimura Y, Pendleton R, Harms J, Collins E, Lee B. A systematic approach for scale-down model development and characterization of commercial cell culture processes. Biotechnol Prog 2006; 22:696-703.

3. Kelley B. Industrialization of $\mathrm{mAb}$ production technology: The bioprocessing industry at a crossroads. mAbs 2009; 1:443-52.

4. Spens E, Häggström L. Defined protein and animal component-free NS0 fed-batch culture. Biotechnol Bioeng 2007; 98:1183-94.

5. Cruz HJ, Moreira JL, Carrondo MJT. Metabolic shifts by nutrient manipulation in continuous cultures of BHK cells. Biotechnol Bioeng 1999; 66:104-13.

6. Seifert DB, Phillips JA. The production of monoclonal antibody in growth-arrested hybridomas cultivated in suspension and immobilized modes. Biotechnol Prog 1999; 15:655-66.

7. Pau MG, Ophorst C, Koldijk MH, Schouten G, Mehtali M, Uytdehaag F. The human cell line PER.C6 provides a new manufacturing system for the production of influenza vaccines. Vaccine 2001; 19:2716-21.

8. Yang J-D, Lu C, Stasny B, Henley J, Guinto W, Gonzalez C, et al. Fed-batch bioreactor process scaleup from $3 \mathrm{~L}$ to $2,500 \mathrm{~L}$ scale for monoclonal antibody production from cell culture. Biotechnol Bioeng 2007; 98:141-54.

9. Keen MJ, Steward TW. Adaptation of cholesterolrequiring NS0 mouse myeloma cells to high density growth in a fully defined protein-free and cholesterol-free culture medium. Cytotechnology 1995; 17: 203-11.

10. Gorfien S, Paul B, Walowitz J, Keem R, Biddle W, Jayme D. Growth of NSO cells in protein-free, chemically defined medium. Biotechnol Prog 2000; 16: 682-7.

11. Seth G, Ozturk M, Hu WS. Reverting cholesterol auxotroph of NS0 cells by altering epigenetic gene silencing. Biotechnol Bioeng 2006; 93:820-7.

12. Hartman TE, Sar N, Genereux K, Barritt DS, He YM, Burky JE, et al. Derivation and characterization of cholesterol-independent non-GS NS0 cell lines for production of recombinant antibodies. Biotechnol Bioeng 2007; 96:294-306.

13. Birch JR, Racher JR. Antibody production. Adv Drug Delivery Rev 2006; 58:671-85.
14. Li F, Kao E, Ryll TA. Generic High Cell Mass Fedbatch Process for NS0 Cells. Poster Presentation, Cell Culture Engineering IX, March 7-12, 2004; Cancun, Mexico.

15. Burky JE, Wesson MC, Young A, Farnsworth S, Dionne B, Zhu Y, et al. Protein-free fed-batch culture of non-GS NS0 cell lines for production of recombinant antibodies. Biotechnol Bioeng 2006; 96:281-93.

16. Alex Z, Rosa H. Anti-N-glycolylneuraminic acid antibodies identified in healthy human serum. Xenotransplantation 2002; 9:376-81.

17. Byres E, Paton AW, Paton JC, Lofling JC, Smith DF, Wilce MCJ, et al. Incorporation of a non-human glycan mediates human susceptibility to a bacterial toxin. Nature 2008; 456:648-52.

18. Tangvoranuntakul P, Gagneux P, Diaz S, Bardor M Varki N, Varki A, et al. Human uptake and incorporation of an immunogenic nonhuman dietary sialic acid. Proc Natl Acad Sci USA 2003; 100:12045-50.

19. Jones DH, Kroos N, Anema R, Van Montfort B, Vooys A, Van der Kraats S, et al. High-level expression of recombinant $\mathrm{IgG}$ in the human cell line PER.C6. Biotechnol Prog 2003; 19:163-8.

20. Jayapal KP, Wlaschin KF, Hu W-S, Yap MGS. Recombinant protein therapeutics from CHO cells-20 years and counting. Chem Eng Prog 2007; 103:40-7.

21. Boshart M, Weber F, Jahn G, Dorsch-Hasler K, Fleckenstein B, Schaffher W. A very strong enhancer is located upstream of an immediate early gene of human cytomegalovirus. Cell 1985; 41:521.

22. Deer JR, Allison DS. High-level expression of proteins in mammalian cells using transcription regulatory sequences from the Chinese hamster EF-1 alpha gene. Biotechnol Prog 2004; 20:880-9.

23. Kozak M. Point mutations define a sequence flanking the AUG initiator codon that modules translation by eukaryotic ribosomes. Cell 1986; 44:283-92.

24. Shen AY, Van de Goor J, Zheng L, Reyes AE, Krummen LA. Recombinant DNA technology and cell line development. In: Ozturk SS, Hu W-S, eds. Cell culture technology for pharmaceutical and cellbased therapies. Boca Raton, FL: CRC Press, Taylor \& Francis Group 2006; 15-40.

25. Davis J, Jiang LY, Pan L-Z, LaBarre MU, Andersen D, Reff M. Expression of GnTIII in recombinant antiCD20 CHO production cell line: expression of antibodies with altered glycoforms leads to an increase in ADCC through higher affinity for FcyRIII. Biotechnol Bioeng 2001; 74:288-94.
26. Saba JA, Kunkel JP, Jan DCH, Ens WE, Standing KG, Butler M, et al. A study of immunoglobulin G glycosylation in monoclonal and polyclonal species by electrospray and matrix-assisted laser desorption/ionization mass spectrometry. Anal Biochem 2002; 305:16-31.

27. Kanda Y, Imai-Nishiya H, Kuni-Kamochi R, Katsuhiro M, Inoue M, Kitajima-Miyama K, et al. Establishment of a GDP-mannose 4,6-dehydrase (GMD) knockout host cell line: A new strategy for generating completely non-fucosylated recombinant therapeutics. J Biotechnol 2007; 130:300-10.

28. Mori K, Kamochi RK, Ohnuki NY. Engineering Chinese hamster ovary cells to maximize effector function of produced antibodies using FUT8 siRNA. Biotechnol Bioeng 2004; 88:901-8.

29. Sauerwald TM, Figueroa BJ, Hardwick JM, Oyler GA Betenbaugh MJ. Combining caspase and mitochondrial dysfunction inhibitors of apoptosis to limit cell death in mammalian cell cultures. Biotechnol Bioeng 2006; 94:362-72.

30. Chen K, Liu Q, Xie L-Z, Sharp PA, Wang DI. Engineering of a mammalian cell line for reduction of lactate formation and high monoclonal antibody production. Biotechnol Bioeng 2001; 72:55-61.

31. Kim SH, Lee GM. Downregulation of lactate dehydrogenase-A by siRNAs for reduced lactic acid formation of Chinese hamster ovary cells producing thrombopoietin. Appl Microbiol Biotechnol 2007; 74:152-9.

32. Jeong D-W, Cho IT, Kim TS, Bae GW, Kim I-H, Kim IY. Effects of lactate dehydrogenase suppression and glycerol-3-phosphate dehydrogenase overexpression on cellular metabolism. Mol Cell Biochem 2006; 284:1-8.

33. Bi J-X, Shuttleworth J, Al-Rubeai M. Uncoupling of cell growth and proliferation results in enhancement of productivity in $\mathrm{p} 21^{\text {cip } 1}$-arrested $\mathrm{CHO}$ cells. Biotechnol Bioeng 2004; 85:741-9.

34. Wolf AP. When more is less. Nat Genet 1998; 18:5-6.

35. Coroadinho AS, Schucht R, Gama-Norton L, Wirth D, Hauser H, Carrondo MJ. The use of recombinase mediated cassette exchange in retroviral vector producer cell lines: predictability and efficiency by transgene exchange. J Biotechnol 2006; 124:457-68.

36. Fukushige S, Sauer B. Genomic targeting with a positive-selection lox integration vector allows highly reproducible gene expression in mammalian cells. Proc Natl Acad Sci 1992; 89:7905-9.

37. Kito M, Itami S, Fukano Y, Yamana K, Shibui T. Construction of engineered $\mathrm{CHO}$ strains for high-level production of recombinant proteins. Appl Microbiol Biotechnol 2002; 60:442-8. 
38. Andersen DC, Reilly DE. Production technologies for monoclonal antibodies and their fragments. Curr Opinion Biotechnol 2004; 15:456-62.

39. Li H, Sethuraman N, Stadheim TA, Zha D, Prinz B, Ballew N, et al. Optimization of humanized IgGs in glycoengineered Pichia pastoris. Nat Biotech 2006; 24:210-5

40. Simmons LC, Reilly D, Klimowski L, Raju TS, Meng G, Sims P, et al. Expression of full-length immunoglobulins in Escherichia coli: rapid and efficient production of aglycosylated antibodies. J Immunol Methods 2002; 263:133-47.

41. Mazor Y, Van Blarcom V, Mabry R, Iverson BL, Georgiou G. Isolation of engineered, full length antibodies from libraries expressed in Escherichia coli. Nat Biotechnol 2007; 25:563-5

42. Ward M, Lin C, Victoria DC, Fox BP, Fox JA, Wong DL, et al. Characterization of Humanized Antibodies Secreted by Aspergillus niger. Appl Environ Microbiol 2004; 70:2567-76.

43. Goerke AR, Swartz JR. Development of cell-free protein synthesis platforms for disulfide bonded proteins. Biotechnol Bioeng 2008; 99:351-67.

44. Butler M. Animal cell cultures: recent achievements and perspectives in the production of biopharmaceuticals. Appl Microbiol Biotechnol 2005; 68:283-91.

45. Walsh G, Jefferis R. Post-translational modifications in the context of therapeutic proteins. Nat Biotech 2006 24:1241-52.

46. Gawlitzek M, Estacio M, Furch T, Kiss R. Identification of cell culture conditions to control $\mathrm{N}$-glycosylation site-cccupancy of recombinant glycoproteins expressed in CHO cells. Biotechnol Bioeng 2009; 103:1164-75.

47. Fletcher $T$. Designing culture media for recombinant protein production: A rational approach. BioProcess International 2005; 3:30-6.

48. Vijayasankaran N, Li J, Shawley R, Chen A, Shiratori M, Gawlitzek M, et al. Animal Cell Culture Media. In: Flickinger MC, ed. Encyclopedia of Industria Biotechnology, Bioprocess, Bioseparation, and Cell Technology: John Wiley \& Sons, Inc., 2010.

49. Heidemann R, Zhang C, Qi H, Larrick Rule J, Rozales $\mathrm{C}$, Park S, et al. The use of peptones as medium additives for the production of a recombinant therapeutic protein in high density perfusion cultures of mammalian cells. Cytotechnology 2000; 32:157-67.

50. Franek F, Hohenwarter O, Katinger H. Plant protein hydrolysates: Preparation of defined peptide fractions promoting growth and production in animal cells cultures. Biotechnol Prog 2000; 16:688-92.

51. Zhou W, Rehm J, Europa A, Hu W-S. Alteration of mammalian cell metabolism by dynamic nutrient feeding. Cytotechnology 1997; 24:99-108.

52. Zhou W, Rehm J, Hu WS. High viable cell concentration fed-batch cultures of hybridoma cells through on-line nutrient feeding. Biotechnol Bioeng 1995; 46:579-87.

53. Xie LZ, Wang DIC. High cell density and high monoclonal antibody production through medium design and rational control in a bioreactor. Biotechnol Bioeng 1996; 51:725-9.

54. Castro PML, Hayter PM, Ison AP, Bull AT. Application of a statistical design to the optimization of culture medium for recombinant interferon-gamma production by Chinese hamster ovary cells. Appl Microbiol Biotechnol 1992; 38:84-90.

55. Hammett K, Kuchibhatla J, Hunt C, Holdread S, Brooks J. Developing chemically defined media through DOE: Complete optimization with increased protein production in less than 8 Months. In: Smith R, ed. Cell Technology for Cell Products. Dordrecht, Netherlands: Springer Netherlands 2007;683-91.

56. Harcum S. Protein glycosylation. In: Ozturk SS, Hu WS, eds. Cell culture technology for pharmaceutical and cell-based therapies. Boca Raton, FL: CRC Press 2006:113-53.
57. Guidance for Industry PAT-A Framework for Innovative Pharmaceutical Development, Manufacturing, and Quality Assurance. Food and Drug Administration (FDA) 2004.

58. Gnoth S, Jenzsch M, Simutis R, Lübbert A. Process Analytical Technology (PAT): Batch-to-batch reproducibility of fermentation processes by robust proces operational design and control. J Biotechnol 2007; 132:180-6.

59. Furukawa K, Ohsuye K. Enhancement of productivity of recombinant $\alpha$-amidating enzyme by low temperature culture. Cytotechnology 1999; 31:85-94.

60. Moore A, Mercer J, Dutina G, Donahue CJ, Bauer $\mathrm{KD}$, Mather JP, et al. Effects of temperature shift on cell cycle, apoptosis and nucleotide pools in $\mathrm{CHO}$ cell batch culture. Cytotechnology 1997; 23:47-54.

61. Fox SR, Tan HK, Tan MC, Wong SC, Yap MG, Wang DI, et al. A detailed understanding of the enhanced hypothermic productivity of interferon-gamma by Chinese-hamster ovary cells. Biotechnol Appl Biochem 2005; 41:255-64.

62. Fleischaker RJ, Sinskey AJ. Oxygen demand and supply in cell culture. Appl Microbiol Biotechnol 1981; 12:193-7.

63. Miller WM, Wilke CR, Blanch HW. Effect of dissolved oxygen on hybridoma growth and metabolism in continuous culture. J Cell Physiol 1987; 132:524-30.

64. Ozturk SS, Palsson BO. Effects of dissolved oxygen on hybridoma cell growth, metabolism and antibody production kinetics in continuous cultures. Biotechnol Prog 1990; 6:437-46.

65. Kunkel JP, Jan DCH, Jamieson JC, Bulter M. Dissolved oxygen concentration in serum-free continuous culture affects $\mathrm{N}$-linked glycosylation of a monoclonal antibody. J Biotechnol 1998; 62:55-71.

66. Garnier A, Voyer R, Tom R, Perret S, Jardin B, Kamen A. Dissolved carbon dioxide accumulation in a large scale high cell density production of TGF $\beta$ receptor with baculovirus infected Sf-9 cells. Cytotechnology 1996; 22:53-63

67. Gray DR, Cgen S, Howarth W, Inlow D, Maiorella L. $\mathrm{CO}_{2}$ in large-scale and high density $\mathrm{CHO}$ cell perfusion culture. Cytotechnology 1996; 22:65-78.

68. Kimura R, Miller WM. Glycosylation of CHO-derived recombinant tPA produced under elevated $\mathrm{pCO}_{2}$. Biotechnol Prog 1997; 73:311-7.

69. Wayte J, Boraston R, Bland H, Varley J, Brown M. pH effects on growth productivity of cell lines producing monoclonal antibodies: control in large scale fermenters. Cytotechnology 1997; 22:87-94.

70. Schmid G, Blanch HW, Wilke CR. Hybridoma growth, metabolism and product formation in HEPES buffered media: II: Effect of pH. Biotechnol Lett 1990; 12:633-8.

71. deZengotita VM, Schmelzer AE, Miller WM. Characterization of hybridoma cell responses to elevated $\mathrm{pCO}_{2}$ and osmolality: intracellular $\mathrm{pH}$, cell size, apoptosis and metabolism. Biotechnol Bioeng 2002; 77:369-80.

72. Zhu MM, Goyal A, Rank DL, Gupta SK, Boom TV, Lee SS. Effects of elevated $\mathrm{pCO}_{2}$ and osmolality on growth of $\mathrm{CHO}$ cells and production of antibodyfusion protein B1: A case study. Biotechnol Prog 2005; 21:70-7.

73. Maiorella B, Inlow D, Howarth W. Method of increasing product expression through solute stress. United States Patent US 6,238,891 B1.

74. Chen M, Forman LW. Polypeptide production in animal cell culture. United States Patent US 6,180,401 B1.

75. Seewöster T, Lehmann J. Cell size distribution as parameter for the predetermination of exponential growth during repeated batch cultivation of $\mathrm{CHO}$ cells. Biotechnol Bioeng 1997; 55:793-7.
76. Xing Z, Kenty BM, Li ZJ, Lee SS. Scale-up analysis for a $\mathrm{CHO}$ cell culture process in large-scale bioreactors. Biotechnol Bioeng 2009; 103:733-46.

77. Rathore AS, Noferi JF, Arling ER, Sofer G, Watler P O'Leary R. Process validation how much to do and when to do it. BioPharm International 2002; 15:18-28.

78. FDA Guidance for Industry: Q5E Comparability of Biotechnological/Biological Products Subject to Changes in Their Manufacturing Process. June 2005, http://wwwfdagov/cder/guidance/indexhtm.

79. Rathore AS, Wang A, Menon M, Riske F, Campbell J, Goodrich E, et al. Optimization, scale-up and validation issues in filtration of biopharmaceuticals- Part I. BioPharm International 2004; 17:50-8.

80. Seely JE, Seely R. A rational, step-wise approach to process characterization. BioPharm Int 2003; 16:24-34.

81. Goochee CF. The roles of a process development group in biopharmaceutical process startup. Cytotechnology 2002; 38:63-76.

82. Chirino AJ, Mire-Sluis A. Characterizing biological products and assessing comparability following manufacturing changes. Nat Biotechnol 2004; 22:1383-91.

83. Kensy F JG, Hofmann B, Büchs J. Characterization of operation conditions and online monitoring of physiological culture parameters in shaken 24-well microtiter plates. Bioprocess Biosyst Eng 2005; 75:75-81.

84. Micheletti M, Barrett T, Doig SD, Baganz F, Levy MS, Woodley JM, et al. Fluid mixing in shaken bioreactors: implications for scale-up predictions from microliterscale microbial and mammalian cell cultures. Chemical Engineering Science 2006; 61:2939-49.

85. De Jesus MJ, Girard P, Bourgeois M, Baumgartner G Jacko B, Amstutz H, et al. TubeSpin satellites: a fast track approach for process development with anima cells using shaking technology. Biochem Eng J 2004; 17:217-23.

86. Legmann R, Schreyer HB, Combs RG, McCormick EL, Russo AP, Rodgers ST. A predictive high-throughput scale-down model of monoclonal antibody production in CHO cells. Biotechnol Bioeng 2009; 104 1107-20.

87. Chen A, Chitta R, Chang D, Amanullah A. Twentyfour well plate miniature bioreactor system as a scaledown model for cell culture process development. Biotechnol Bioeng 2009; 102:148-60.

88. Amanullah A, Otero JM, Mikola MR, Hsu A, Zhang J Aunins J, et al. Evaluation of Simcell technology for cell culture process development. Biochemical Engineering XV, Quebec City, Canada 2007; July 15-19 2007.

89. Derfus GE, Abramzon D, Tung M, Chang D, Kiss R, Amanullah A. Cell culture monitoring via an autosampler and an integrated multi-functional off-line analyzer. Biotechnol Prog 26:284-92.

90. Konstantinov KB, Pambuyan R, Matanguihan R, Yoshida T, Purusich CM, Hu WS. On-line monitoring of hybridoma cell growth using a laser turbidity sensor. Biotechnol Bioeng 1992; 40:1337-42.

91. Zeiser A, Bedard C, Voyer R, Jardin B, Tom R, Kamen A. On-line monitoring of the progress of infection in Sf-9 insect cell cultures using relative permittivity measurements. Biotechnol Bioeng 1999; 63:122-6.

92. Chung H, Arnold M, Rhiel M, Murhammer D. Simultaneous measurement of glucose and glutamine in aqueous solutions by near infrared spectroscopy. Appl Biochem Biotechnol 1995; 50:109-25.

93. Riley MR, Okeson CD, Frazier BL. Rapid calibration development for near-infrared spectroscopic monitoring of mammalian cell cultivations. Biotechnol Prog 1999; 15:1133-41.

94. Riley MR, Crider HM, Nite ME, Garcia RA, Woo J, Wegge RM. Simultaneous measurements of 19 components in animal cell culture media by near infrared spectroscopy. Biotechnol Prog 2001; 17:376-8. 
95. Yano T, Harata M. Prediction of the concentration of several constituents in a mouse-mouse hybridoma culture by near infrared spectroscopy. J Ferment Bioeng 1994; 77:659-62.

96. Harms PKY, French JA, Soliman M, Anjanappa M, Ram A, Rao G. Design and performance of a 24-station high throughput microbioreactor. Biotechnol Bioeng 2006; 93:6-13.

97. Eibl D, Eibl R. Bioreactors for Mammalian Cells: General Overview. Cell and Tissue Reaction Engineering: Springer Berlin Heidelberg 2008; 55-82.
98. Eibl R, Eibl D. Disposable bioreactors for cell culture based-bioprocessing. Achema Worldwide News 2007; 8-10.

99. Seth G, Philp RJ, Lau A, Jiun KY, Yap M, Hu WS Molecular portrait of high productivity in recombinant NS0 cells. Biotechnol Bioeng 2006; 97:933-51.

100. Wlaschin KF, Seth G, Hu WS. Toward genomic cell culture engineering. Cytotechnology 2006; 50:121-40. 